\title{
PLANTAE KRUKOVIANAE VI ${ }^{1}$
}

\author{
A. C. Smith
}

THE PRESENT PAPER is based primarily upon plants collected in Amazonian Brazil by Mr. B. A. Krukoff. The first set of his collections, including the types of new species here described, is deposited in the herbarium of the New York Botanical Garden. The first set of duplicates is deposited at Harvard University (woody plants at the Arnold Arboretum, herbaceous plants at the Gray Herbarium). Other duplicate sets are widely distributed in American and European institutions.

\section{ARACEAE}

Philodendron amplectens A. C. Smith, sp. nov.

Planta epiphytica scandens; caudice gracili verruculis minutis asperato, 4-8 mm. crasso, ad nodos radicante, internodiis elongatis 18-22 $\mathrm{cm}$. longis; petiolis supra leviter canaliculatis siccitate striatis, verruculis minutis densissime obtectis, basi vagina decidua circiter $2 \mathrm{~cm}$. longa instructis, 7-11 cm. longis; laminis coriaceis anguste oblongo-deltoideosagittatis, $11-15 \mathrm{~cm}$. longis, basi $5.5-7.5 \mathrm{~cm}$. latis, apice breviter acuminatis, lobis posticis oblongis apice rotundatis circiter $4 \mathrm{~cm}$. longis et $2.5 \mathrm{~cm}$. latis sinu lato parabolico sejunctis, nervis lateralibus primariis costalibus quam secundariis atque tertiariis vix crassioribus, basalibus 2 paullo validioribus, nervo collectivo a margine circiter $1 \mathrm{~mm}$. remoto; pedunculo tereti $44.5 \mathrm{~cm}$. longo; spatha ovato-oblonga medio leviter constricta, $9.5-10 \mathrm{~cm}$. longa, expansa $4-5.5 \mathrm{~cm}$. lata, convoluta $1.5-2 \mathrm{~cm}$. diametro, apice breviter apiculata; spadice conspicue stipitato (stipite circiter $15 \mathrm{~mm}$. longo et $4 \mathrm{~mm}$. diametro) quam spatha paullo breviore, inflorescentia feminea circiter $2.5 \mathrm{~cm}$. longa, 6-8 mm. crassa, mascula $4-4.5 \mathrm{~cm}$. longa apice obtusa; pistillo subcylindrico circiter $3 \mathrm{~mm}$. longo et $1.5 \mathrm{~mm}$. diametro, 3- vel 4-loculari, multiovulato, stigmate truncato coronato; floribus masculis 3-vel 4-andris, circiter $2 \mathrm{~mm}$. longis.

Type, Krukoff 7250, collected Nov. 15, 1934, on margin of Rio Ipixuna between Monte Christo and Santa Victoria, Municipality Humayta,

${ }^{1}$ Previous papers in this series have been published as follows:

I: Bull. Torrey Club 60:349-365, 379-396. pl. 21, 22. 1933.

II: Bull. Torrey Club 61: 191-196. 1934.

III: (by H. A. Gleason): Phytologia 1: 106-111. 1934.

IV: Phytologia 1: 113-126. 1935.

V: Brittonia 2: 145-164. 1936. 
basin of Rio Madeira, Amazonas. A species of Engler's Section PolySPERMium, it is related to P. Jenmanii Krause and P. scabrum Krause, particularly resembling the latter by its scabrid petiole. Than either of these species, however, $P$. amplectens has a much narrower leaf blade and a longer inflorescence stipe. Philodendron scabrum has a comparatively short spadix and the pistil is described as several-loculed.

Philodendron solimoesensis A. C. Smith, sp. nov.

Planta epiphytica; petiolis siccitate valde striatis basi teretibus apicem versus supra leviter canaliculatis, circiter $45 \mathrm{~cm}$. longis, inferne $6-7 \mathrm{~mm}$. diametro; laminis coriaceis oblongo-sagittatis, 40-55 cm. longis, basin versus $20-23 \mathrm{~cm}$. latis, lobis posticis triangulari-oblongis sinu profundo acuto distantibus, 19-20 cm. longis, ad $12 \mathrm{~cm}$. latis, apice obtusis, lobo antico oblongo-triangulari apice obtusis, nervis lateralibus primariis utroque circiter 4 a costa patentibus quam secundariis atque tertiariis multo validioribus, basalibus 2 in costulas in sinu longe $(3-4 \mathrm{~cm}$.) denudatas conjunctis, nervis secundariis et tertiariis prominulis in nervum collectivum a margine circiter $0.5 \mathrm{~mm}$. remotum conjunctis; pedunculo 5-6 mm. crasso ut videtur brevi; spatha siccitate coriacea apice acuta medio leviter constricta, circiter $20 \mathrm{~cm}$. longa, convoluta 2.5-4 cm. diametro; spadice stipite brevi suffulto, inflorescentia feminea circiter $8 \mathrm{~cm}$. longa et $2-2.5 \mathrm{~cm}$. diametro, mascula circiter $8 \mathrm{~cm}$. longa et $1.5 \mathrm{~cm}$. diametro, apice obtusa; baccis subcylindricis, 7-9 mm. longis, 5-6 mm. diametro, 5-locularibus, stigmatibus subrotundatis coronatis.

Type, Krukoff 8861, collected Oct.-Dec., 1936, on terra firma in basin of Creek Belem, Municipality São Paulo de Olivença, basin of Rio Solimoes, Amazonas. A species of Engler's Section Polyspermium, it is remarkable for the elongate-triangular basal lobes of its sagittate leaves. From P. maculatum Krause, a near ally, the new species differs in foliage and also in its substantially larger inflorescence.

Heteropsis linearis A. C. Smith, sp. nov.

Caudex alte scandens; ramulis crassis striatis nigrescentibus $3-5 \mathrm{~mm}$. crassis, teretibus vel apicem versus paullo complanatis, internodiis 2-4 $\mathrm{cm}$. longis; petiolis $1.5-2 \mathrm{~mm}$. crassis striatis supra canaliculatis $3-7 \mathrm{~mm}$. longis; laminis rigide coriaceis linearibus vel angustissime oblongis saepe falcatis, $15-22 \mathrm{~cm}$. longis, $1.8-2 \mathrm{~cm}$. latis, basi attenuatis, apice acutis vel calloso-apiculatis, margine crassis et leviter recurvatis, nervis lateralibus numerosis valde adscendentibus utrinque distincte prominulis prope marginem conjunctis; ramulis floriferis brevibus terminalibus; pedunculo tereti conspicue striato $8-10 \mathrm{~mm}$. longo; spatha non visa; spadice (stipite 6-7 mm. longo suffulto) in siccitate nigrescente oblongo, florifero circiter 
$35 \mathrm{~mm}$. longo et $7 \mathrm{~mm}$. diametro, apice obtuso; pistillo vertice $3-5 \mathrm{~mm}$. lato, stigmate oblongo instructo.

Type, Krukoff 8781, collected Oct.-Dec., 1936, in high forest on terra firma in basin of Creek Belem, Municipality São Paulo de Olivença, basin of Rio Solimoes, Amazonas. It is a very distinct species on the basis of its long and extremely narrow leaves. Heteropsis rigidifolia Engl., apparently the closest relative of the new species, has leaves not exceeding $15 \mathrm{~cm}$. in length and not less than $2.5 \mathrm{~cm}$. broad, as well as a shorter spadix.

Heteropsis macrophylla A. C. Smith, sp. nov.

Caudex alte scandens; ramulis crassis 4-8 mm. diametro striatis nigrescentibus teretibus, internodiis $2-4 \mathrm{~cm}$. longis; petiolis $3-4 \mathrm{~mm}$. crassis striatis profunde canaliculatis $9-12 \mathrm{~mm}$. longis; laminis rigide coriaceis anguste oblongis, $18-30 \mathrm{~cm}$. longis, $5-7 \mathrm{~cm}$. latis, supra nitidis, basi obtusis, apice obtusis vel breviter cuspidatis, margine leviter undulatis, nervis lateralibus numerosis rectis adscendentibus utrinque prominulis in nervum collectivum a margine circiter $0.5 \mathrm{~mm}$. remotum conjunctis; ramulis floriferis axillaribus circiter $8 \mathrm{~cm}$. longis; pedunculo crasso tereti striato $12-20 \mathrm{~mm}$. longo; spatha non visa; spadice (stipite brevi suffulto) oblongo, florifero 5-6 cm. longo et medio $1-1.3 \mathrm{~cm}$. diametro, apice obtuso; pistillo vertice $3-5 \mathrm{~mm}$. lato, stigmate punctiformi coronato.

Type, Krukoff 7151, collected Nov. 11, 1934, on terra firma on the plateau between Rio Livramento and Rio Ipixuna, Municipality Humayta, basin of Rio Madeira, Amazonas. It is a species characterized by fine coriaceous shining leaves, the largest so far reported for the genus. From H. Jenmani Oliv., apparently its closest ally, the new species differs by having its leaves less gradually narrowed at the extremities and lacking an acuminate tip, and by having a very regular collecting nerve extremely close to the leaf margin.

\section{SMILACACEAE}

Smilax Krukovii A. C. Smith, sp. nov.

Frutex scandens ubique glaber ut videtur inermis; ramulis teretibus gracilibus; petiolis gracilibus saepe tortuosis $10-17 \mathrm{~mm}$. longis, vetustioribus basi prope ad medium anguste vaginatis, vaginis valde apiculatis; laminis chartaceo-coriaceis opacis supra nitidis lanceolato- vel ovatooblongis, $10-12 \mathrm{~cm}$. longis, $3.5-5.7 \mathrm{~cm}$. latis, basi cuneato-attenuatis, apice breviter apiculato-acuminatis, margine integris undulatis, 5-nerviis, nervis extimis marginalibus et inconspicuis, nervis alteris supra pro- 
minulis subtus prominentibus, venulis reticulatis utrinque prominulis; pedunculis masculis solitariis quam petiolis multo brevioribus, $3-5 \mathrm{~mm}$. longis; receptaculis globosis circiter $4 \mathrm{~mm}$. diametro, bracteolis coriaceis minutis ovatis; pedicellis gracilibus $3-4 \mathrm{~mm}$. longis; floribus ut videtur 18-25 per inflorescentiam, alabastris $3-3.5 \mathrm{~mm}$. longis; perianthii segmentis oblongis apice incurvatis, exterioribus circiter $1.5 \mathrm{~mm}$. latis, interioribus paullo angustioribus; filamentis brevissimis (ad $0.5 \mathrm{~mm}$. longis), antheris oblongis obtusis circiter $2 \mathrm{~mm}$. longis.

Type, Krukoff 8964, collected Oct.-Dec., 1936, on shore of creek, basin of Creek Belem, Municipality São Paulo de Olivença, basin of Rio Solimoes, Amazonas. It is a species related to $S$. eucalyptifolia Kunth and its allies, differing from them by its short peduncles, smaller receptacles, and smaller flowers. From S. gilva Macbride of adjacent Peru, which it closely resembles in foliage, the new species differs by its globose rather than elongate receptacles, its shorter pedicels, and its somewhat smaller flowers with proportionately shorter filaments.

\section{Smilax graciliflora A. C. Smith, sp. nov.}

Frutex scandens ubique glaber; ramulis teretibus parce tuberculatis 2.5-4 mm. crassis, aculeis paucis recurvis $2-5 \mathrm{~mm}$. longis armatis; petiolis 15-40 mm. longis, usque ad $1 / 3$ marginibus inflexis extremitate ut videtur decidue cirrhiferis vaginatis; laminis valde coriaceis opacis anguste ovato-oblongis, $20-27 \mathrm{~cm}$. longis, $6.5-10.5 \mathrm{~cm}$. latis, basi obtusoattenuatis, apice breviter acuminatis (acumine obtuso $1-1.5 \mathrm{~cm}$. longo), margine integris, 5-nerviis, nervis extimis marginalibus et inconspicuis, nervis alteris supra conspicue impressa subtus prominentibus, venulis reticulatis supra obscuris vel leviter elevatis subtus prominulis; squamis basi ramorum coriaceis ovato-oblongis ad $1 \mathrm{~cm}$. longis; racemis axillaribus ad $13 \mathrm{~cm}$. longis; pedunculis masculis in axillis bractearum oblongarum 6-10 $\mathrm{mm}$. longarum gracilibus $15-30 \mathrm{~mm}$. longis; receptaculis subglobosis 2-3 mm. diametro, bracteolis oblongo-lanceolatis $0.5-1 \mathrm{~mm}$. longis; umbellis masculis 30-60-floris; pedicellis gracilibus 5-8 mm. longis; perianthii segmentis anguste oblongis, exterioribus circiter $5 \mathrm{~mm}$. longis et $1.3-1.5 \mathrm{~mm}$. latis, interioribus paullo minoribus vel similibus; filamentis brevissimis $(0.5 \mathrm{~mm}$. longis), antheris oblongis obtusis 2-2.6 $\mathrm{mm}$. longis, dorso squamis minutis argenteis oblongis circiter $0.1 \mathrm{~mm}$. longis copiose lineolatis.

Type, Krukoff 8806, collected Oct.-Dec., 1936, in high forest on terra firma, basin of Creek Belem, Municipality São Paulo de Olivença, basin of Rio Solimoes, Amazonas. It is a species characterized by its large coriaceous leaves with the primary nerves impressed above, its slender 
peduncles and pedicels, its many-flowered umbels, and its dorsally silverlineolate anthers. Its relationship is with $S$. cinnamomea Desf. and its allies.

\section{MENISPERMACEAE}

\section{Odontocarya tripetala Diels}

Colombia. B o y a c á : Mt. Chapon Region, Lawrance 302 (type coll.). Brazil. A m a z o n a s : Municipality São Paulo de Olivença, near Palmares, basin of Rio Solimoes, Krukoff 8182. Bolivia. B e n i : Rurrenabaque, Cardenas 1873.

The above cited collections indicate the wide distribution which is frequent in Menispermaceae. Dissections of staminate flowers show that the anthers are transversely dehiscent, a character which seems to remove the species from Odontocarya. Three petals are also not found elsewhere in the genus. The inflorescence branching suggests Somphoxylon, but here also, as in the related Synandropus, the anthers are vertically dehiscent. For the time being, Diels' placing of the species is accepted, but future revision of these genera will probably make a separation necessary.

Somphoxylon magnifolium A. C. Smith, sp. nov.

Frutex scandens; ramulis teretibus striatis; petiolis glabris striatis gracilibus (circiter $1.5 \mathrm{~mm}$. crassis) 4-6 cm. longis, basi et apice incrassatis; laminis chartaceis vel papyraceis glabris plus minusve translucidis elliptico-oblongis, 25-28 cm. longis, 11-12 cm. latis, basi rotundatis vel obtuso-rotundatis, apice breviter acuminatis (acumine 7-9 mm. longo apiculato), margine integris, nervis lateralibus 7 vel 8 arcuatoadscendentibus cum costa supra elevatis subtus prominentibus, venulis copiose et arcte reticulatis utrinque prominulis; inflorescentiis masculis perfectis non visis, ramulis minutissime puberulis demum glabris, ramulis primariis gracilibus $7-8 \mathrm{~cm}$. longis, ramulis secundariis $4-8 \mathrm{~mm}$. longis; floribus plerumque solitariis, bracteis ovatis minutis ad $0.5 \mathrm{~mm}$. longis subtentis, breviter pedicellatis vel sessilibus; sepalis 3 exterioribus deltoideis obtusis circiter $0.5 \mathrm{~mm}$. longis et latis, 3 interioribus membranaceis suborbicularibus valde concavis circiter $1 \mathrm{~mm}$. longis et latis; petalis 6 subobovatis vel obcuneatis, circiter $0.8 \mathrm{~mm}$. longis, 0.3-0.5 mm. latis, marginibus inflexis; staminibus 3 circiter $0.6 \mathrm{~mm}$. longis, filamentis connatis, antheris filamenta aequantibus per rimas verticales dehiscentibus.

Type, Krukoff 7035, collected Nov. 6, 1934, on terra firma, along Rio Livramento, Municipality Humayta, basin of Rio Madeira, Amazonas. Among the three species recognized to date, S. magnifolium most 
nearly resembles in leaf shape and venation $S$. Klugii A. C. Smith, a species with much smaller leaves, with more ample inflorescences as evinced by the secondary branches being $2.5-4 \mathrm{~cm}$. long, and with larger flowers. From $S$. Wullschlaegelii Eichl. the new species differs by having its leaves proportionately narrower, its inflorescence apparently more compact, and its flowers conspicuously smaller. The leaf blades of $S$. Wullschlaegelii are 5-nerved from the base, or at least the basal pair of nerves has conspicuous proximal branches; $S$. magnifolium has leaf blades simply 3-nerved from the base.

\section{MONIMIACEAE}

Siparuna pachyantha A. C. Smith, sp. nov.

Arbor monoecia ad $20 \mathrm{~m}$. alta, trunco $12-18 \mathrm{~cm}$. diametro; ramulis crassis rugulosis fuscis juventute arcte et densissime lepidoto-tomentellis demum glabris; foliis ramulorum prope apices confertis; petiolis crassis valde canaliculatis $1.5-3.5 \mathrm{~cm}$. longis, ut ramulis novellis tomentellis; laminis chartaceis siccitate fuscis obovato-ellipticis vel elliptico-oblongis, 21-36 cm. longis, $11-15 \mathrm{~cm}$. latis, basi longe attenuatis, apice ut videtur breviter cuspidatis, margine undulatis et leviter revolutis, utrinque praecipue ad nervos stellato-lepidoto-pilosis demum glabrescentibus, pinnatinerviis, costa valida subtus prominente, nervis secundariis utroque 15-17 rectis patulis prope margines conspicue anastomosantibus supra leviter elevatis subtus prominentibus, venulis utrinque prominulis; inflorescentiis axillaribus cymosis plerumque binis $2-6.5 \mathrm{~cm}$. longis, ramulis (cum floribus) densissime stellato-lepidoto-tomentellis; floribus sessilibus vel senectute breviter (ad $2 \mathrm{~mm}$.) pedicellatis, magnitudine valde diversis, obovoideo-globosis, masculis $1.5-3.5 \mathrm{~mm}$. diametro, bracteis 2 vel 3 lineari-oblongis $1-1.5 \mathrm{~mm}$. longis subtentis; receptaculo valde carnoso; tepalis obsoletis; velo leviter conico-elevato, ore minuto; staminibus 2 deltoideis carnosis $0.5-0.8 \mathrm{~mm}$. longis, basi $0.6-0.8 \mathrm{~mm}$. latis, antheris quam filamentis longioribus, per poros ovales contiguos $0.3-0.5 \mathrm{~mm}$. longos dehiscentibus; floribus femineis depresso-globosis quam masculis majoribus ad $4.5 \mathrm{~mm}$. latis; stylis 6-10 ut videtur leviter cohaerentibus non exsertis.

Type, Krukoff 8674, collected Oct.-Dec., 1936, in high forest on terra firma in basin of Creek Belem, Municipality São Paulo de Olivença, basin of Rio Solimoes, Amazonas. Another collection from the same region is Krukoff 8667 . Pistillate flowers are very few and appear to be confined to the lower parts of the inflorescence (or lacking on most inflorescences). In the treatment of Perkins and Gilg in the Pflanzenreich, the new species should be sought near S. cristata (P.\& E.) A. DC., 
S. lepidantha Perk., and S. sarmentosa Perk., but actually it is not very closely related to these, appearing to have no near allies, at least in lowland South America. The thick flowers with only 2 stamens (a constant character in the many flowers examined), the lack of tepals, and the large attenuate-based leaves place the species in an isolated position in the genus.

\section{CELASTRACEAE}

Maytenus Krukovii A. C. Smith, sp. nov.

Arbor glabra ad $28 \mathrm{~m}$. alta; ramulis teretibus (vel juventute leviter complanatis) gracilibus mox cinereis; petiolis rugosis anguste alatis vel conspicue canaliculatis $6-9 \mathrm{~mm}$. longis; laminis coriaceis siccitate olivaceis vel fuscis oblongo-ellipticis vel obovato-ellipticis, 9-14 $(-18) \mathrm{cm}$. longis, 3.5-5 $(-7) \mathrm{cm}$. latis, basi attenuatis et in petiolum decurrentibus, apice acuminatis (acumine ad $10 \mathrm{~mm}$. longo ut videtur obtuso), margine leviter revolutis et superne obscure crenato-serratis, costa utrinque prominente, nervis lateralibus utroque 7-9 adscendentibus prope margines anastomosantibus supra immersis et obscuris subtus leviter prominulis, venulis obscuris; inflorescentiis axillaribus glomerulatis 4-5 mm. diametro; floribus sessilibus vel subsessilibus (pedicellis ad $0.5 \mathrm{~mm}$. longis) numerosissimis (50 vel ultra per inflorescentiam), bracteis minutis; calyce cupuliformi, sepalis deltoideis subacutis, 0.8-1 mm. longis, circiter $0.6 \mathrm{~mm}$. latis, apicem versus minute glanduloso-fimbriatis; petalis imbricatis oblongo-deltoideis, $0.8-1.2 \mathrm{~mm}$. longis, circiter $0.8 \mathrm{~mm}$. latis, apice obtusis vel rotundatis; filamentis minutis $0.2 \mathrm{~mm}$. longis apice angustatis; antheris deltoideo-ovoideis, circiter $0.5 \mathrm{~mm}$. longis et latis, basi profunde cordatis, apice minute mucronulatis; disco carnoso circiter $1.2 \mathrm{~mm}$. diametro margine undulato; ovario in disco immerso, stylo crasso circiter $0.4 \mathrm{~mm}$. longo inconspicue lobato; capsula oblongoobovoidea coriacea, circiter $20 \mathrm{~mm}$. longa et $14 \mathrm{~mm}$. lata, valvis 2, pericarpio $1-1.5 \mathrm{~mm}$. crasso.

Type, Krukoff 4957, collected June 21, 1933, on terra firma near mouth of Rio Embira (tributary of Rio Tarauaca), basin of Rio Jurua, Amazonas. Other collections are: between Rio Madeira and Rio Capana, Krukoff 7310, 7311. The type is in flower; 7310 is accompanied by a single imperfect fruit; 7311 is sterile. There is little doubt that the specimens are conspecific, although 7311 has slightly larger leaves than the other two.

Maytenus Krukovii closely resembles $M$. laurina Briq. of the Rio Negro in leaf shape and texture, but differs by having its smooth upper leaf surfaces with immersed nerves, while $M$. laurina has the nerves and veinlets sharply impressed above. The inflorescence of $M$. laurina, 
although congested, is not strictly glomerulate as that of the new species. Maytenus Krukovii also resembles M. Radlkoferiana Loes., but differs by having its leaves less conspicuously serrulate and its flowers much more numerous and essentially sessile.

The collector states that this is probably the same species known in Peru as "chuchuhuasca," mentioned by LeCointe. ${ }^{1}$ The bark is considered a powerful stimulant and yields an alkaloid similar to cathin, from the leaves of Catha edulis Forsk.

Maytenus micrantha A. C. Smith, sp. nov.

Arbor glabra ad $25 \mathrm{~m}$. alta; ramulis patulis subteretibus gracilibus juventute fuscis mox cinereis; petiolis rugosis anguste alatis vel supra complanatis $5-9 \mathrm{~mm}$. longis; laminis coriaceis vel crasse chartaceis siccitate olivaceo-fuscis oblongis vel oblongo-ellipticis, $7-11 \mathrm{~cm}$. longis, $2.3-4.5 \mathrm{~cm}$. latis, basi obtusis et in petiolum decurrentibus, apice ut videtur obtuse acuminatis, margine leviter revolutis et superne obscure crenatis, costa utrinque prominente, nervis lateralibus utroque 10-12 patulis prope margines adscendentibus utrinque manifeste elevatis, venulis utrinque minute prominulis vel obscuris; inflorescentiis axillaribus fasciculatis $3-5 \mathrm{~mm}$. diametro; floribus subsessilibus (pedicellis sub anthesi $0.5-0.7 \mathrm{~mm}$. longis) numerosissimis; bracteis oblongis circiter $0.8 \mathrm{~mm}$. longis, apicem versus fimbriatis; sepalis imbricatis late deltoideis obtusis, circiter $0.6 \mathrm{~mm}$. longis, $0.8-1 \mathrm{~mm}$. latis; petalis imbricatis oblongis obtusis circiter $0.7 \mathrm{~mm}$. longis et latis; filamentis minutis, antheris globoso-deltoideis circiter $0.3 \mathrm{~mm}$. diametro; disco carnoso circiter $0.7 \mathrm{~mm}$. diametro; ovario in disco immerso, stylo crasso circiter $0.3 \mathrm{~mm}$. longo minute lobato.

Type, Krukoff 6596, collected Oct. 13, 1934, on terra firma near Livramento, on Rio Livramento, basin of Rio Madeira, Amazonas. It is a species characterized by compact inflorescences and extremely small flowers, closely resembling the preceding (M. Krukovii) in inflorescence characters, but differing by its somewhat smaller leaves which are thinner in texture and with spreading lateral nerves obvious on both surfaces. From another allied species which it resembles in leaf shape, M. ebenifolia Reiss., the new species differs by having its lateral nerves raised rather than impressed above and by its subsessile smaller flowers.

\section{OCHNACEAE}

Krukoviella A. C. Smith, gen. nov.

Flores magni 5-meri. Sepala imbricata, 2 exteriora quam interiora ${ }^{1}$ LeCointe, P. Arvores e plantas uteis, 120. 1934 (Para). 
paullo minora. Petala lutea imbricata. Staminodia nulla. Stamina 10 uniseriata ovarium cingentia non secunda; filamentis brevibus ligulatis; antheris erectis, loculis 2 per porum unicum terminalem dehiscentibus. Ovarium fusiforme; placentis 5 fere ad ovarii centrum valde intrusis, hic bifurcatis retroflexis; ovulis numerosissimis in 10 cumulis linearibus arcte imbricatis, uno margine et apice angustissime membranaceo-alatis. Stylus subnullus. Stigmata 5 sessilia minuta linearia radiatim adnata.

Frutex scandens. Folia alternata simplicia; nervis secundariis pinnatis paucis; nervis tertiariis et venulis aequabiliter reticulatis. Stipulae mox caducae, cicatricibus marginibus superioribus ciliatis. Inflorescentiae terminales paniculatae.

The new genus is named in honor of Mr. B. A. Krukoff, in recognition of the value of the thousands of specimens he has collected in Amazonian Brazil in recent years.

Krukoviella is quite unique in the Ochnaceae because of its lack of the subulate style characteristic of the family and its 5 radiating sessile stigmas, which suggest certain genera of Guttiferae. It falls into the Tribe Luxemburgieae, in which, because of the absence of staminodes as well as in inflorescence and foliage characters, it can be related only to Cespedesia Goudot and Godoya R. \& P., being especially close to the latter. In addition to the stigmatic differences, Krukoviella differs from Godoya as follows: sepals glabrous rather than ciliate at base within; petals bilobed at anthesis rather than entire; stamens in one row rather than two; anthers with a single terminal pore rather than two; placentae parietal rather than axillary. The new plant is said by the collector to be a liana; it has the tertiary nerves hardly distinguishable from the copiously reticulate veinlets and not conspicuously parallel. The species of Godoya, on the other hand, are trees; they have the tertiary nerves more or less parallel and usually distinguishable from the veinlets. The stamens of the new genus, in young flowers, are regularly disposed about the ovary, and even at anthesis there is no intimation of zygomorphy as in Godoya and its other allies, which have- the ovary and stamens divergently secund.

Krukoviella scandens A. C. Smith, sp. nov.

Frutex scandens ubique glaber; ramulis teretibus striatis fuscocinereis parce lenticellatis; stipulis coriaceis oblongis vel oblongoobovatis ad $7 \mathrm{~mm}$. longis et $5 \mathrm{~mm}$. latis, apice rotundatis, basi latis, cicatricibus cilia nigra ad $1 \mathrm{~mm}$. longa marginibus superioribus gerentibus; petiolis rugosis supra subplanis $4-7 \mathrm{~mm}$. longis, superne anguste 
alatis; laminis coriaceis siccitate supra olivaceis subtus fuscis obovatis, $7-14 \mathrm{~cm}$. longis, $3-6.5 \mathrm{~cm}$. latis, basi acutis vel attenuatis, apice rotundatis et minute mucronulatis vel leviter emarginatis, margine revolutis et crenato-dentatis (dentibus inconspicuis 3-6 per centimetrum), costa utrinque valde prominente, nervis secundariis utroque 14-18 patulis leviter curvatis conspicuis utrinque valde prominulis, nervis tertiariis et venulis copiose reticulatis utrinque prominulis; inflorescentiis sub anthesi ad $18 \mathrm{~cm}$. longis et $10 \mathrm{~cm}$. latis, pedunculo ad $4 \mathrm{~cm}$. longo cum rhachi tereti striato recto, ramulis secundariis alternatis patulis infra nodos saepe complanatis; floribus numerosis, pedicellis gracilibus sub anthesi $6-8 \mathrm{~mm}$. longis superne leviter incrassatis; sepalis coriaceis erectis concavis ovatis vel ovato-oblongis, 2 exterioribus $3-4 \mathrm{~mm}$. longis et circiter $3 \mathrm{~mm}$. latis, 3 interioribus $4-5 \mathrm{~mm}$. longis et $3-4 \mathrm{~mm}$. latis, apice rotundatis, margine integris, basi leviter auriculatis; petalis tenuiter coriaceis obovatis vel obdeltoideis, $10-13 \mathrm{~mm}$. longis, 6-8 $\mathrm{mm}$. latis, juventute integris, sub anthesi apice bilobatis (sinu ad $5 \mathrm{~mm}$. alto, lobis rotundatis), basi ad $1 \mathrm{~mm}$. angustatis, margine apicem versus anguste involutis; filamentis carnosis, $1.5-1.8 \mathrm{~mm}$. longis, basi circiter $0.5 \mathrm{~mm}$. latis, apice leviter incrassatis; antheris mox caducis linearioblongis, $4-5 \mathrm{~mm}$. longis, circiter $1.3 \mathrm{~mm}$. latis, basi truncatis vel leviter auriculatis, apice obtuse cuspidatis, apiculo circiter $0.3 \mathrm{~mm}$. longo, poro minuto; ovario verruculoso leviter 5-sulcato breviter stipitato, sub anthesi 7-9 mm. longo, medio circiter $2 \mathrm{~mm}$. diametro, basi et apice angustato, apice subacuto; stigmatibus albis circiter $0.2 \mathrm{~mm}$. longis.

Type, Krukoff 8908, collected Oct.-Dec., 1936, on terra firma in high forest, basin of Creek Belem, Municipality São Paulo de Olivença, Amazonas.

\section{CARYOCARACEAE}

Caryocar pallidum A. C. Smith, sp. nov.

Arbor ad $25-35 \mathrm{~m}$. alta ubique glabra; ramulis robustis teretibus fusco-cinereis, cicatricibus stipularum mox delapsarum inconspicuis; petiolis teretibus striatis (2-) $5-11 \mathrm{~cm}$. longis; stipellis plerumque 2 conspicuis curvatis 4-9 $\mathrm{mm}$. longis saepe persistentibus; petiolulis supra subplanis subaequalibus gracilibus $4-10 \mathrm{~mm}$. longis; laminis chartaceis vel tenuiter coriaceis siccitate fuscis subaequalibus (terminalibus paullo maximis, lateralibus saepe basi inaequilateralibus) ellipticis, $7-15 \mathrm{~cm}$. longis, $3.5-6.5 \mathrm{~cm}$. latis, basi acutis vel obtusis, apice obtuse cuspidatis (acumine $5-10 \mathrm{~mm}$. longo), margine cartilagineis et conspicue serratis (serraturis 2-3 per centimetrum apice obtusis vel inconspicue apiculatis), costa supra acute elevata subtus prominente, nervis lateralibus 
utroque 8-12 adscendentibus prope margines anastomosantibus supra subplanis subtus prominulis, venulis copiose reticulatis supra saepe leviter impressis subtus subplanis; pedunculis crassis $8-10 \mathrm{~cm}$. longis; racemis 15-25-floris, rhachi $3-4 \mathrm{~cm}$. longa copiose lenticellata; pedicellis adscendentibus siccitate valde striatis sub anthesi $15-35 \mathrm{~mm}$. longis, prophyllis nullis; calyce 5-7 mm. longo et summo 9-12 $\mathrm{mm}$. diametro, basi in stipitem crassum $3-5 \mathrm{~mm}$. longum abrupte contracto, lobis 5 deltoideo-ovatis obtusis $4-5 \mathrm{~mm}$. longis et $5-6 \mathrm{~mm}$. latis; petalis et filamentis albis vel flavescentibus; petalis sub anthesi obovato-oblongis, 15-23 mm. longis, 8-13 mm. latis, apice rotundatis et saepe concavis, basi paullo angustatis, margine minutissime serrulatis; staminibus numerosissimis, filamentis filiformibus $2-3 \mathrm{~cm}$. longis, basi in annulum $2-4 \mathrm{~mm}$. longum connatis.

Type, Krukoff 7011, collected Nov. 2-19, 1934, on terra firma on the plateau between Rio Livramento and Rio Ipixuna, basin of Rio Madeira, Amazonas. Another collection is: Amazonas: basin of Rio Purus: San Carlos, about 100 miles above Labrea, on terra firma, Krukoff 5824. The new species is characterized by its comparatively small white or yellowish flowers, including the filaments, and its glabrous coarsely serrate leaflets with fine reticulate venation. In foliage characters, it closely resembles $C$. crenatum Wittm., from which it differs by the absence of tufted hairs in the axils of secondary nerves, by the absence of pedicellary bractlets, and by its fewer-flowered racemes. Caryocar dentatum Gleason, another species with dentate leaflets, has conspicuous pubescence on the petioles, petiolules, lower surfaces of leaflet blades, pedicels, and calyx, and has conspicuously longer filaments. The flower color of neither $C$. crenatum nor $C$. dentatum has been recorded. The Peruvian $C$. Tessmannii Pilger, somewhat similar in general appearance to $C$. pallidum, has scarlet filaments, less distinctly serrate leaflet margins, axillary hair tufts on the lower surfaces of leaflet blades, and no stipels.

Caryocar parviflorum A. C. Smith, sp. nov.

Arbor nobilis ad $45-55 \mathrm{~m}$. alta ubique glabra; ramulis robustis teretibus fuscis saepe lenticellatis, cicatricibus stipularum mox delapsarum inconspicuis; petiolis subteretibus vel apicem versus plus minusve complanatis striatis $2-6 \mathrm{~cm}$. longis; stipellis plerumque 2 involutis curvatis 2-3 mm. longis plerumque persistentibus; petiolulis subaequalibus leviter canaliculatis $3-10 \mathrm{~mm}$. longis; laminis tenuiter coriaceis vel chartaceis siccitate fusco-olivaceis subaequalibus ellipticis vel obovato-ellipticis, 5-9 cm. longis, $2.5-5 \mathrm{~cm}$. latis, basi acutis vel cuneatis (lateralibus paullo 
inaequilateralibus), apice obtuse cuspidatis (acumine $2-7 \mathrm{~mm}$. longo saepe calloso-mucronulato), margine cartilagineis subintegris vel undulatis vel remote et inconspicue crenatis, costa supra leviter elevata subtus prominente, nervis lateralibus utroque 8-11 patulis prope margines anastomosantibus utrinque prominulis, venulis copiose reticulatis supra saepe leviter prominulis; pedunculis crassis 5-6 $\mathrm{cm}$. longis; racemis 10-25-floris, rhachi $2-5.5 \mathrm{~cm}$. longa lenticellata; pedicellis siccitate valde striatis sub anthesi $10-20 \mathrm{~mm}$. longis, prophyllis nullis; calyce 4-5 mm. longo et summo 9-11 mm. diametro, basi in stipitem crassum 1-2 mm. longum abrupte contracto, lobis 5 semiorbicularibus circiter $3 \mathrm{~mm}$. longis et 3-5 mm. latis; petalis sub anthesi obovatis, 18-25 mm. longis, 11-13 $\mathrm{mm}$. latis, apice rotundatis, basi angustatis, margine minute erosis; staminibus numerosissimis, filamentis exterioribus coccineis $27-33 \mathrm{~mm}$. longis, basi in annulum brevem connatis, interioribus brevioribus moniliformibus flavescentibus, antheris oblongis ad $0.5 \mathrm{~mm}$. longis; stylis flavescentibus filamentis exterioribus subaequalibus.

Type, Krukoff 6599, collected Oct. 13, 1934, on terra firma near Livramento, on Rio Livramento, Municipality Humayta, basin of Rio Madeira, Amazonas. Another collection from the same general region is Krukoff 6438, from restinga alta near Tres Casas. A local name is "Piquiarana," which is elsewhere used to designate C. glabrum (Aubl.) Pers. Like C. glabrum, its closest relative, $C$. parviflorum is a tree of the high forest above flood-level with red or scarlet outer filaments. It may be distinguished from that widespread species primarily by its smaller flowers, of which the outer filaments of fully mature and fallen flowers hardly exceed $3 \mathrm{~cm}$. in length, those of $C$. glabrum usually being about $6 \mathrm{~cm}$. long. The leaflets of the new species appear to be somewhat smaller on the average, more obovate in outline, and more consistently entire than those of $C$. glabrum, and the stipels are more persistent. It is quite likely that future collection of the fruits or nuts will give additional characters to separate the two plants, since in the genus as a whole the fruits provide very reliable characters.

\section{GUTTIFERAE}

Vismia cauliflora A. C. Smith, sp. nov.

Frutex vel arbor gracilis ad $8 \mathrm{~m}$. alta; ramulis crassis teretibus juventute dense rufo- vel ferrugineo-tomentosis mox glabrescentibus et cinereis; petiolis crassis (4-6 $\mathrm{mm}$. diametro) 3-15 mm. longis ut ramulis densissime tomentosis; laminis coriaceis anguste obovato-oblongis, 30-45 $\mathrm{cm}$. longis, $8-13 \mathrm{~cm}$. latis, basi anguste rotundatis vel leviter subcordatis, 
apice breviter acuminatis (acumine ad $20 \mathrm{~mm}$. longo), margine anguste recurvatis et leviter undulatis, siccitate fusco-olivaceis, supra praeter costam interdum plus minusve tomentellam glabris, subtus nigropunctatis et dense (costa et nervis densissime) pilis stellatis rufoferrugineis tomentellis, costa supra subplana et interdum canaliculata subtus prominentissima, nervis secundariis utroque 18-25 patulis prope margines conspicue anastomosantibus supra impressis et saepe paullo prominulis subtus prominentibus; inflorescentiis e ramulis vel ramis infra folia orientibus glomerulatis, glomerulis conspicuis 1-2 cm. diametro multifloris; floribus sessilibus magnis; calycis laciniis oblongis, 5-6 mm. longis, 1.5-3 mm. latis, apice obtusis, nigro-lineolatis, extra saepe dense rufo-pubescentibus (pilis stellatis 3-5-ramosis patulis $0.4-0.7 \mathrm{~mm}$. diametro), interioribus margine scariosis; petalis lineari-oblongis, 10-12 $\mathrm{mm}$. longis, 1.5-2 mm. latis, nigro-punctatis, apice obtusis, intra dense et pallide villosis; staminodiis oblongis $1.5-1.7 \mathrm{~mm}$. longis obtusis, apicem versus parce villosis; staminum phalangibus ligulatis, 5-6 mm. longis, circiter $0.7 \mathrm{~mm}$. latis, intra parce villosis, filamentis specialibus 10-13 glabris, antheris subglobosis $0.3-0.4 \mathrm{~mm}$. diametro; ovario leviter angulato glabro, stylis carnosis teretibus $7-8 \mathrm{~mm}$. longis, stigmatibus subcapitatis; fructibus (ut videtur immaturis) ovoideis, 6-7 mm. longis, 4-5 mm. latis, stylis coronatis.

Type, Krukoff 7947, collected in August, 1936, in an old clearing along road to Aleixo, Municipality Manaos, basin of Rio Negro, Amazonas. Another collection is: Amazonas: Municipality Humayta: basin of Rio Madeira, near Livramento, on terra firma, Krukoff 6976. Like other species of the genus, it is known as "Lacre." Although obviously a member of the Section Euvismia, V. cauliflora, by virtue of the arrangement of its crowded sessile flowers in glomerules on the old branchlets, appears very distinct from any other described species. The extraordinarily large obovate leaves, narrowed toward the base, and the dense ferruginous tomentum of branchlets, principal leaf nerves, etc., also characterize the species.

\section{MYRSINACEAE}

Conomorpha madeirensis A. C. Smith, sp. nov.

Arbor ad $6 \mathrm{~m}$. alta; ramulis teretibus fuscis juventute minute ferrugineo-tomentellis mox glabris; petiolis gracilibus rugosis $10-18 \mathrm{~mm}$. longis; laminis chartaceis siccitate fuscis ellipticis, $11-15 \mathrm{~cm}$. longis, $5-8.5 \mathrm{~cm}$. latis, basi acutis et in petiolum decurrentibus, apice obtusis vel rotundatis, margine integris et leviter recurvatis, utrinque (supra inconspicue) punctulis minutissimis pictis, costa supra plana vel leviter elevata 
subtus prominente et rugosa, nervis secundariis numerosis parallelis patulis prope margines conspicue anastomosantibus utrinque valde prominulis, venulis reticulatis leviter prominulis; inflorescentiis laxe racemosis $8-13 \mathrm{~cm}$. longis multifloris solitariis, pedunculo brevi et rhachi petiolisque minutissime ferrugineo-tomentellis; pedicellis $0.5-1 \mathrm{~mm}$. longis; sepalis fere ad basim liberis deltoideo-oblongis 1-1.3 mm. longis, parce glanduloso-lineolatis, apice obtusis, margine integris et minute glanduloso-fimbriatis; corolla extra glabra $3-3.5 \mathrm{~mm}$. longa, lobis ad $1 / 3$ connatis oblongis circiter $1.5 \mathrm{~mm}$. latis, apice obtusis, intra minute et dense farinoso-pulverulentibus; staminibus circiter $1 \mathrm{~mm}$. supra basim corollae insertis, filamentis ligulatis $0.3-0.5 \mathrm{~mm}$. longis, antheris deltoideooblongis $0.8-1 \mathrm{~mm}$. longis, basi cordatis, apice obtusis; ovario conico sub anthesi circiter $0.6 \mathrm{~mm}$. longo obscure sed dense lepidoto, stylo circiter $1.3 \mathrm{~mm}$. longo truncato.

Type, Krukoff 7240, collected Nov. 15, 1934, on margin of Rio Ipixuna between Monte Christo and Santa Victoria, Municipality Humayta, basin of Rio Madeira, Amazonas. It is a species of the alliance of $C$. grandiflora Mez and C. magnoliifolia Mez, both of which have coriaceous leaves strongly revolute at margins and conspicuous pedicels. In foliage, the new species more closely resembles $C$. obovata $\mathrm{Mez}$, but that species has much longer pedicels and sessile anthers.

\section{EBENACEAE}

Diospyros tenuiflora A. C. Smith, sp. nov.

Frutex ad $5 \mathrm{~m}$. altus; ramulis gracilibus teretibus fuscis juventute copiose puberulis mox glabris; petiolis gracilibus subteretibus $5-10 \mathrm{~mm}$. longis fusco-strigosis; laminis tenuiter coriaceis siccitate olivaceo-fuscis anguste oblongis, $15-24 \mathrm{~cm}$. longis, $4.5-6.5 \mathrm{~cm}$. latis, basi rotundatis vel leviter obtusis, apice longe acuminatis (acumine gracili ad $15 \mathrm{~mm}$. longo obtuso), supra praeter costam strigulosam glabris, subtus ad nervos pallide puberulis, costa supra profunde impressa subtus prominente, nervis secundariis utroque 9-12 prope margines conspicue anastomosantibus utrinque valde elevatis, venulis conspicue et copiose reticulatis utrinque prominulis; inflorescentiis of axillaribus glomerulosis paucifloris; pedicellis ad $2 \mathrm{~mm}$. longis fusco-strigosis; calyce campanulato circiter $5 \mathrm{~mm}$. longo ubique dense et arcte flavido-sericeo (pilis $0.3-0.5$ $\mathrm{mm}$. longis), lobis 4 suberectis deltoideo-oblongis, sub anthesi circiter $3 \mathrm{~mm}$. longis et $2 \mathrm{~mm}$. latis, acuminatis; corolla crasse carnosa urceolata 10-12 mm. longa, extra minute et parce flavido-sericea intus glabra, limbo apice constricto, apicem versus circiter $3 \mathrm{~mm}$. diametro, lobis 4 
in alabastro imbricatis contortis, circiter $2 \mathrm{~mm}$. latis, apice obtusis; staminibus $10-12$ basi corollae affixis, filamentis glabris ad $1.7 \mathrm{~mm}$. longis, antheris oblongis, 1.7-2 mm. longis, dorsaliter flavido-sericeis, basi leviter cordatis, apice acuminatis, per rimas laterales dehiscentibus; ovario minuto dense setoso.

Type, Krukoff 8431, collected in Sept.-Oct., 1936, on varzea land near Palmares, Municipality São Paulo de Olivença, basin of Rio Solimoes, Amazonas. In vegetative characters, D. tenuiflora most closely resembles D. Tessmannii Mildbr., from which it differs by its shorter petioles, its leaf pubescence, its fewer secondary nerves and more obvious veinlets, and its slightly larger flowers, of which the corollas are only sparsely pubescent. The two species appear to form a distinct group in Hiern's Section Paralea, differing from D. guianensis (Aubl.) Gürke in many details of pubescence and leaf texture.

Diospyros bullata A. C. Smith, sp. nov.

Arbor parva vel frutex ad $7 \mathrm{~m}$. altus (interdum scandens); ramulis crassis teretibus juventute densissime brunneo- vel ferrugineo-tomentellis demum glabris; petiolis crassis (ad $5 \mathrm{~mm}$. diametro) rugosis supra complanatis $10-17 \mathrm{~mm}$. longis ut ramulis tomentellis; laminis coriaceis valde bullatis ovato-ellipticis, $15-30 \mathrm{~cm}$. longis, $8-15 \mathrm{~cm}$. latis, basi leviter cordatis vel rotundatis, apice acuminatis (acumine 8-20 mm. longo), margine conspicue revolutis, supra praeter costam et interdum nervos secundarios tomentella glabris, subtus densissime et constanter hispidis (pilis brunneis vel ferrugineis ad $0.6 \mathrm{~mm}$. longis), costa et nervis secundariis utroque 7-10 adscendentibus prope marginem conspicue anastomosantibus supra valde impressis subtus valde prominentibus, venulis reticulatis supra impressis subtus valde elevatis; inflorescentiis of axillaribus cymosis ad $2 \mathrm{~cm}$. longis $8-14$-floris, ramulis pedicellis calycibusque densissime ferrugineo-tomentellis (pilis circiter $0.5 \mathrm{~mm}$. longis); bracteis oblongis ad $5 \mathrm{~mm}$. longis acutis intus glabris caducis; pedicellis $3-5 \mathrm{~mm}$. longis; calyce coriaceo sub anthesi circiter $8 \mathrm{~mm}$. longo, lobis ovato-deltoideis subacutis, 5-6 mm. longis, 3-4 mm. latis; corolla carnosa basi extra parce strigosa vel ubique glabra sub anthesi circiter $8 \mathrm{~mm}$. longa profunde 5-lobata, lobis alabastri valde imbricatis sub anthesi rotatis ovato-oblongis obtusis, 5-6 mm. longis, circiter $3 \mathrm{~mm}$. latis, basi subauriculatis; staminibus circiter 50 corollae basi affixis 2-4-seriatis, filamentis subglabris $0.4-0.8 \mathrm{~mm}$. longis, antheris lineari-oblongis $2.2-3.5 \mathrm{~mm}$. longis dorsaliter conspicue setosis (pilis ad $1 \mathrm{~mm}$. longis) apice obtusis; ovario nullo; inflorescentiis $q$ eis supra descriptis plus minusve similibus; calyce ad $12 \mathrm{~mm}$. longo, lobis elongato- 
deltoideis, $8-10 \mathrm{~mm}$. longis, $5-7 \mathrm{~mm}$. latis; corolla sub anthesi circiter $12 \mathrm{~mm}$. longa, lobis $8-10 \mathrm{~mm}$. longis, $5-6 \mathrm{~mm}$. latis; staminodiis circiter 18 circiter $2 \mathrm{~mm}$. supra basim corollae affixis linearibus $1.7-3 \mathrm{~mm}$. longis setosis (pilis circiter $2 \mathrm{~mm}$. longis); ovario subgloboso densissime luteoferrugineo-setoso (pilis 1.3-1.8 mm. longis), loculis 6, 1-ovulatis, stylis 3 carnosis basi liberis praeter apices strigosis, apice bifidis; calyce sub fructo valde accrescente coriaceo ad $5 \mathrm{~cm}$. diametro intus constanter sericeo, lobis patulis ad $2 \mathrm{~cm}$. longis et $1.5 \mathrm{~cm}$. latis; fructibus subglobosis ad $3 \mathrm{~cm}$. diametro basim versus 5 -angulatis, densissime longe setosis vel distaliter glabrescentibus, apice mucronulatis, pericarpio valde coriaceo 1.5-2 mm. crasso extra valde ruguloso.

Type, Krukoff 8004, collected in August, 1936, in high forest on terra firma along road to Aleixo, Municipality Manaos, basin of Rio Negro, Amazonas. Other collections from essentially the same locality are Killip \& Smith 30113, Ducke 360, 366. The flowers are said to be very fragrant, the corollas white without and rosy within. Staminate flowers are described from Ducke 366, pistillate from Ducke 360, and fruits from the type, which is selected because of abundance of foliage material. On the basis of its 6-celled ovary, D. bullata would fall into $M a b a$ in Hiern's treatment, but recent students have generally preferred to merge this with Diospyros. In Maba, the new species would be sought in Hiern's Section Trichanthera, in which the size, texture, and venation of the leaves immediately distinguish it. On the basis of corolla shape, stamens, etc., it is best placed in the section Rospidios of Diospyros, where it has no very close allies. In flower size and texture, as well as in foliage, it bears a resemblance to D. longistyla A. C. Smith, but the bullate leaves and different pubescence of the new species, as well as the number of locules and styles, differentiate it.

New York Botanical Garden. 


\section{$2 \mathrm{BHL}$ Biodiversity Heritage Library}

Smith, A C. 1939. "Plantae Krukovianae VI." Journal of the Arnold Arboretum 20(3), 288-303. https://doi.org/10.5962/p.325780.

View This Item Online: https://www.biodiversitylibrary.org/item/33596

DOI: https://doi.org/10.5962/p.325780

Permalink: https://www.biodiversitylibrary.org/partpdf/325780

\section{Holding Institution}

Missouri Botanical Garden, Peter H. Raven Library

\section{Sponsored by}

Missouri Botanical Garden

\section{Copyright \& Reuse}

Copyright Status: In copyright. Digitized with the permission of the rights holder.

Rights Holder: Arnold Arboretum of Harvard University

License: http://creativecommons.org/licenses/by-nc-sa/3.0/

Rights: https://biodiversitylibrary.org/permissions

This document was created from content at the Biodiversity Heritage Library, the world's largest open access digital library for biodiversity literature and archives. Visit BHL at https://www.biodiversitylibrary.org. 